argues that as both conservationists and shooters want as many birds as possible they have a basic common interest; they should work together and not squabble amongst themselves. In both his jobs he had done a great deal to bring this about. Yet in reading Birds in the Balance one wonders if he does not believe that sportsmen are better at conservation than the avowed conservationists. He refers to the breeding and release of greylag geese by the Wildfowlers Association: 'I doubt myself if anything has been more imaginative and its education value seems to me to be much greater than most of the ideas protectionists have hitherto thought up."

The best parts of the book are the author's personal reminiscences of trying to catch egg collectors and dealers after the Protection of Birds Act, 1954, had been enacted. On the whole this activity was remarkably successful and it is a pity that there should have been little happening in the last few years although 'there is ample evidence to show that their activities continue almost unabated.' The official agencies of law enforcement - the police and to a less extent local authorities - do little or nothing on their own initiative.

The book is a readable, discursive but highly personal account of bird protection within the space of a hundred pages. An objective account remains to be written. There are nine pages of photographs of traps, gibbets and oiled birds to emphasise that protection has some way to go before it is effective in these islands.

G. des FORGES

\title{
A Wealth of Wildfowl by Jeffery Harrison. Deutsch, 30 s.
}

Wildfowl can be objects of beauty and fascination to be watched and studied, or a quarry providing a thrilling sport. In previous writings the author has left no doubt that he is in the happy position of being able to enjoy wildfowl in every way, and in this 'Survival' book he ably demonstrates that co-operation between wildfowlers, bird-watchers and biologists really works in this country, to the lasting benefit of the wildfowl and therefore of all those interested in them. Co-operation only came in the last decade, and some of the arguments and wordy battles which preceded the present happier atmosphere are recalled. If this one chapter seems just a little pointless, as indeed may some of the happenings related in it, Dr Harrison uses it as a starting point to show how conservation works in practice, given the necessary precondition of mutual understanding between differing interests.

The quality which comes through on almost every page of the chapters dealing with present research into British wildfowl is enthusiasm. Dr Harrison has himself pioneered or partaken in many of the study methods which he describes. The recent growth in international co-operation in wildfowl conservation is given due prominence and the reader is introduced to many of the leading figures in this field, though an indication of their nationality or position is sometimes lacking. The reader is left sharing Dr Harrison's own undoubted optimism about the present state and future prospects for wildfowl in Britain; that anyone should be able to be optimistic is greatly due to Dr Harrison's own efforts, and this book puts wildfowl further in his debt.

M. A. OGILVIE

\footnotetext{
A BEAUTIFULLY produced, quite slim picture book, with a short authoritaA tive explanatory text, Tracks, (Clarendon Press, 25s.) is a combination of lively drawings by E. A. R. Ennion and revealing photographs by N. Tinbergen, the subjects ranging from a weevil toiling up a sandy slope to wildebeest streaming across the Serengeti; a splendid book for the young naturalist.
}

The Birds of Chile, by A. W. Johnson, reviewed in the May issue of oRYX, can be obtained in Britain from Bernard Quaritch, London, Wheldon and Wesley, Hitchin, or the Scottish Ornithologists' Bookshop, Edinburgh; and in the USA from the Pierce Book Company, Winthrop, Iowa. 